\title{
DASAR-DASAR KOMUNIKASI PERBANKAN SYARIAH
}

Tugas Kelompok Mata Kuliah Komunikasi Bisnis

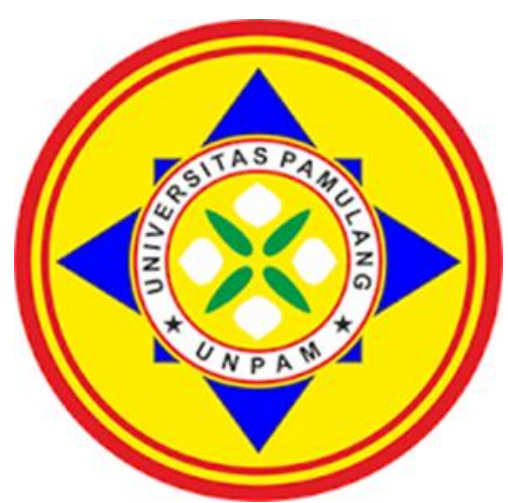

Disusun oleh :

Erlansyah Pandji Anom

Fitriyyah Tawaqal

Hermawan

Nanang

Serly Marsela

Sobri

Wildan Ramdani Ahmad
171010550056

171010551002

171010550017

171010550008

171010550010

171010550078

171010550020

\section{PROGRAM STUDI MANAJEMEN}

FAKULTAS EKONOMI DAN BISNIS

UNIVERSITAS PAMULANG

TANGERANG SELATAN

2021 


\section{DAFTAR ISI}

Judul Halaman

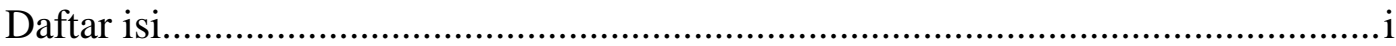

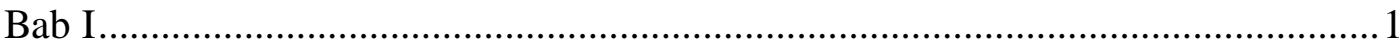

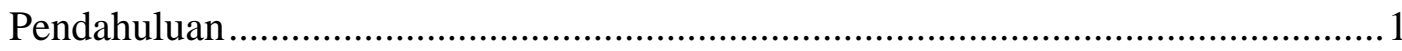

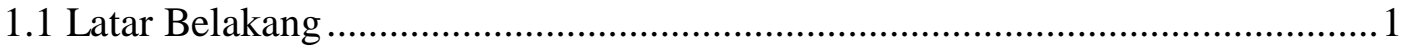

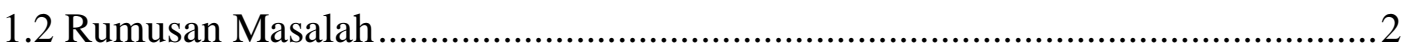

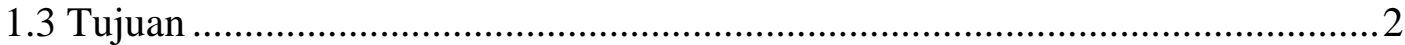

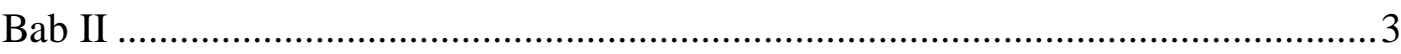

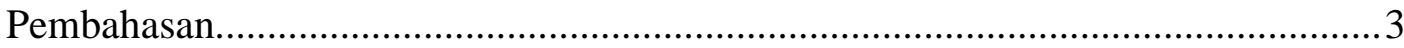

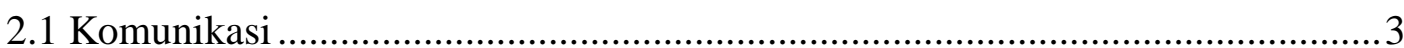

2.2 Bentuk-Bentuk Komunikasi Bisnis Perbankan Syariah ................................... 3

2.3 Proses Komunikasi Bisnis Perbankan Syariah .................................................5

2.4 Keerhasilan Komunikasi Bisnis Perbankan Syariah .......................................6

2.5 Komunikasi Bisnis Perbankan Syariah dalam Konteks Dakwah .......................8

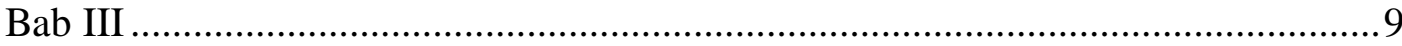

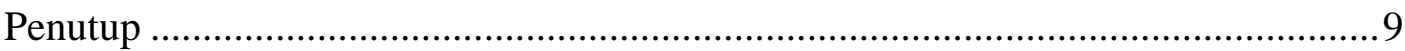

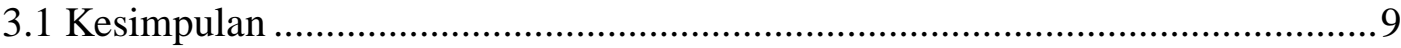

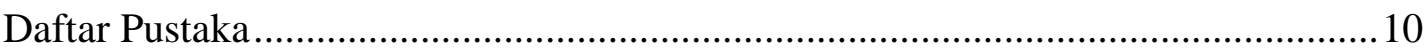




\section{BAB I}

\section{PENDAHULUAN}

\subsection{Latar Belakang}

Perkembangan system keuangan Syariah semakin kuat dengan ditetapkannya undang-undang No. 21 tahun 2008, dimana dalam undang-undang tersebut ditetapkan secara rinci landasan hukum dan jenis-jenis usaha yang dapat dioperasikan oleh perbankan Syariah. Dalam menjalanakan proses bisnisnya, tentu perbankan Syariah harus menjalin hubungan dengan stakeholder, baik internal maupun eksternal. Bentuk hubungan atau proses komunikasi yang terjalin terangkum kedalam komunikasi bisnis. Karena pada dasarnya komunikasi bisnis adalah komunikasi yang terjadi di dunia bisnis, baik verbal maupun nonverbal. tulisan ini menkaji tentang bagaimana bentukbentuk komunikasi bisnis yang terjadi di perbankan Syariah.

Pada dasarnya ada dua bentuk komunikasi yang lazim digunakan dalam dunia bisnis yaitu komunikasi verbal dan komunikasi non verbal, dalam dunia bisnis peran komunikasi verbal sangat dominan, pada setiap fungsi manajerial bisnis mulai dari planning, organizing, actuating, sampai dengan controlling tidak dapat terlaksana tanpa adanya komunikasi verbal. Dapat dibayangkan apabila dalam kegiatan manajerial hanya menggunakan bahasa isyarat. Ketika kita berkomunikasi kita menerjemahkan gagasan kita ke dalam bentuk lambang (verbal atau nonverbal). Bahasa adalah alat penyandian, namun tetap dibutuhkan kecermatan dalam berbahasa, bagaimana mencocokan kata dengan kondisi yang sebenarnya, untuk mengurangi kesalahpahaman dan kerancuan. Komunikasi verbal merupakan salah satu bentuk komunikasi yang disampaikan kepada pihak lain melalui tulisan (written) dan lisan (oral). Komunikasi verbal dapat kita bagi menjadi dua tipe, yaitu berdasarkan aktif dan pasifnya peserta komunikasi dalam proses komunikasi. Komunikasi verbal merupakan salah satu bentuk komunikasi yang lazim digunakan dalam menyampaikan pesan-pesan bisnis kepada pihak lain melalui tulisan maupun lisan.

Komunikasi bisnis adalah proses pertukaran pesan atau informasi untuk mencapai efektivitas dan efisiensi produk kerja di dalam struktur dan sistem organisasi bisnis. Dalam kegiatan komunikasi bisnis, pesan hendaknya tidak hanya sekedar informatif tetapi juga haruslah persuasif, agar pihak lain bersedia menerima suatu paham atau keyakinan atau melakukan suatu perbuatan atau kegiatan. Komunikasi digunakan dalam dunia bisnis yang mencakup berbagai macam jenis dan bentuk 
komunikasi untuk mencapai tujuan bisnis. Oleh karena itu komunikasi yang terjadi di dunia bisnis, tidak boleh melanggar norma-norma bisnis. Dari dimensi komunikasi Harol D. Lasswell menerangkan bahwa setidaknya ada tiga fungsi dasar yang merupakan Hasrat naluriah dan alamiah yang dapat menjelaskan kenapa berkomunikasi. Pertama, karena adanya dalam diri manusia untuk mengontrol lingkungan. Kedua, adalah adanya upaya manusia untuk dapat beradaptasi dengan lingkungan sekitar. Ketiga, adalah upaya manusia untuk mentranformasikan warisan sosialisasi. Melalui komunikasi, manusia dapat melakukan pertukaran ide, gagasan, perilaku, peran dan lain sebagainya. Sedangkan dari dimensi dakwah, aktifitas dakwah menjadi control yang dapat diberikan kestabilan bagi manusia, baik untuk kehidupannya secara kejiwaan di karenakan keinginan untuk mengarah pada keadaan yang lebih baik adalah sesuatu yang sudah ada dalam naruni dasar manusia.

Membahas tentang komunikasi dan dakwah adalah dua buah pembahasan yang sangat menarik untuk dikaji karena dua pembahasan ini sangat berkaitan erat dengan manusia dan kehidupannya dari dulu sampai sekarang.

\subsection{Rumusan Masalah}

1. Bagaimana bentuk-bentuk komunikasi bisnis perbankan syariah?

2. Bagaimana proses komunikasi bisnis perbankan syariah?

3. Bagaimana Keberhasilan Komunikasi bisnis perbankan syariah?

4. Bagaimana komunikasi bisnis perbankan syariah dalam konteks dakwah?

\subsection{Tujuan}

Untuk mengetahui bagaimana dasar-dasar komunikasi yang dilakukan oleh perbankan syariah dalam lingkup kerjanya. 


\section{BAB II}

\section{PEMBAHASAN}

\subsection{Komunikasi}

Secara filosofis, Harold Lasswell mengartikan komunikasi sebagai sebuah proses yang menjelaskan siapa? dengan saluran apa? Kepada siapa? Dengan akibat atau hasil apa? (who? Says what? In which channel? To whom? With what effect?). Secara etimologi, komunikasi bearsal dari kata "communis" yang dalam Bahasa latin berarti sama, yaitu sama makna dan arti. Komunikasi dalam Bahasa arab diistilahkan alaitisal dan pendanannya di dalam Al-Qur'an ialah pertanyaan.

Adapun uraian beberapa definisi komunikasi oleh para ahli antara lain sebagai berikut :

Menurut Onong Uchana Effendy :

"Proses penyampaian pesan tertentu oleh seseorang kepada orang lain; atau untuk mempengaruhi seseorang baik langsung secara lisan, ataupun tidak langsung secara media sehingga terjadi perubahan sikap, pendapat atau perilaku"

Menurut Zulkifli Abdul Ghani :

"Mengajak manusia kepada jalan dakwah yang lebih menekankan kepada nilai-nilai agama dan social budaya, yakni menggunakan prinsip dan kaidah yang terdapat dalam Al-Qur'an dan Hadits"

Berdasarkan pengertian di atas, Amirullah Ahmad menjelaskan bahwa baik ilmu komunikasi maupun dakwah memiliki kesamaan dimana keduannya sama-sama menggunakan metode (sarana) sehingga proses tranformasi, internalisasi dan eksternalisasi pesan (massage) berdampak pada pencapaian tujuan tertentu.

\subsection{Bentuk-bentuk Komunikasi Bisnis Perbankan Syariah}

Komunikasi bisnis yang efektif sangat tergantung pada keterampilan seseorang dalam mengirim maupun menerima pesan. Secara umum, untuk menyampaikan pesanpesan bisnis, seseorang dapat menggunakan tulisan dan lisan. Sedangkan untuk menerima pesan bisnis, seseorang dapat menggunakan pendengaran dan bacaan. Pada umumnya bentuk kegiatan komunikasi bisnis yang lazim dilakukan di perbankan syariah adalah sebagai berikut :

a. Memasarkan produk dan jasa perbankan, khususnya perkreditan (lending).

b. Melayani nasabah atau calon debitur yang mengajukan permohonan kredit. 
c. Memberikan penjelasan perihal persyaratan dan ketentuan kredit dan membimbing calon debitur melengkapi persyaratan permohonan kredit.

d. melakukan kunjungan setempat (on the spot) ke lokasi usaha calon debitur, untuk memeriksa jalannya usaha dan sekaligus melakukan verifikasi data keuangan dan usaha calon debitur.

e. Memeriksa dan memastikan kebenaran data modal usaha sesuai dengan laporan keuangan.

f. Setelah mengusulkan pemberian kredit, memantau perkembangan usaha debitur sesuai dengan jadwal.

g. Melakukan kunjungan setempat untuk memantau perkembangan usaha debitur secara periodic.

h. Menjalin hubungan baik dengan debitur agar tidak berpindah ke perbankan lain.

i. Membantu debitur apabila dikemudian hari terjadi permasalahan dengan perusahaan seperti keterlambatan pembayaran, dsb. Dalam hal ini account officer menjadi perantara antara debitur dan bank.

Manusia sebagai mahluk social akan saling berkomunikasi dan mempengaruhi satu sama lain dalam hubungan konteks yang beraneka ragam, dengan cara dan gaya yang berbeda-beda. Salah satu karakteristik yang mendasar dari komunikasi adalah pengaitannya dengan perilaku (Behavior), perilaku akan terlihat apabila timbul kontak social, tanpa itu maka perilaku tidak terlihat.

Selain komunikasi verbal, komunikasi non verbal juga memberikan banyak kontribusi pada keseuksesan proses operasional bisnis yang dijalankan oleh perbankan syariah. Menurut teori antropologi, sebelum manusia menggunakan kata-kata mereka telah menggunakan gerakan-gerakan tubuh, bahasa tubuh (body language) sebagai alat untuk berkomunikasi dengan orang lain. Diantara bentuk komunikasi non verbal ini adalah : tersenyum kepada nasabah, melambaikan tangan, menggerakkan gigi untuk menunjukan kemarahan, mengerutkan dahi, bersimpati kepada nasabah, menggelengkan kepala, dll.

Pada dasarnya, komunikasi nonverbal dapat mengambil suatu kesimpulan tentang berbagai macam perasaan orang lain, baik rasa senang, benci, cinta, rindu dan berbagai macam perasaan lainnya. Adapun pentingnya komunikasi non verbal 
adalah sebagai berikut : Menyediakan/memberikan informasi, mengatur alur suatu percakapan, mengendalikan dan mempengaruhi orang lain, dll.

\subsection{Proses Komunikasi Bisnis Perbankan Syariah}

Sebagai suatu proses, komunikasi mempunyai persamaan dengan bagaimana seseorang mengekspresikan perasaan, hal yang berlawanan (kontradiktif), yang sama (selaras,serasi), serta meliputi proses menulis, mendengar, dan mempertukarkan informasi. Menurut Courtland L. Bovee dan John V.Thil dalam Business Comunication Today, proses komunikasi terdiri atas enam tahap yaitu :

1. Pengirim mempunyai suatu ide atau gagasan.

2. Pengirim mengubah ide menjadi suatu pesan.

3. Pengirim menyampaikan pesan.

4. Penerima menerima pesan.

5. Penerima menafsirkan pesan.

6. Penerima memberi tanggapan dan mengirim umpan balik kepada pengirim.

Keenam tahapan dalam proses komunikasi tersebut dapat dijelaskan sebagai berikut : Sebelum melakukan proses komunikasi, syarat utamanya adalah adanya ide/gagasan, karena persepsi bersifat unik, maka ide/gagasan akan ditafsirkan berbeda oleh orang lain. Seorang komunikator harus dapat menyaring hal yang tidak penting/tidak relevan, hal ini biasa disebut dengan abstraksi (abstraction).

Ide yang berbentuk abstrak harus dirubah kedalam bentuk pesan, agar ide dapat diterima dan dimengerti secara sempurna, maka pengirim oesan harus memperhatikan beberapa hal, yaitu subjek (apa yang disampaikan,), maksud dan tujuan, audiens, gaya personal dan latar belakang budaya.

Pesan tidak dapat dipahami pihak lain tanpa adanya pemindahan pesan, hal ini tergantung pada jenis pesan yang disampaikan, kita dapat menggunakan berbagai media komunikasi yang tersedia. Pesan yang diterima adakalanya sempurna, namun tidak jarang hanya sebagian kecil saja. Penafsiran suatu pesan secara teratur bila penerima pesan memahami pesan sebagaimana yang dimaksud oleh pengirim pesan, sementara itu feedback dapat berfungsi sebagai koreksi bagi pengirim. 
Umpan balik memegang peranan penting dalam proses komunikasi, karena ia memberi kemungkinan bagi pengirim untuk menilai efektifitas suatu pesan. Disamping itu, adanya umpan balik dapat menunjukan adanya factor-faktor yang menghambat komunikasi, misalnya perbedaan latar belakang, perbedaan penafsiran kata-kata, dan perbedaan reaksi secara emosional. K. Berlo dalam Sutrisna Dewi menjelaskan unsurunsur komunikasi terdiri atas SMCR yaitu (Sumber, Massage, Chanel, dan Receiver). Disamping itu terdapat 3 unsur lain yaitu feedback, efek, dan lingkungan.

Menurut model komunikasi David K.Berlo, sumber dan penerima dipengaruhi oleh factor-faktor keterampilan komunikasi, sikap, pengetahuan, system social, dan budaya. Pesan dikembangkan berdasarkan elemen, struktur, isi, perlakuan, dank ode. Saluranya berhubungan dengan panca indera, melihat, mendengar, menyentuh, membaui, dan merasa.

Jika komunikasi dipandang sebagai proses, komunikasi yang dimaksud adalah suatu kegiatan yang berlangsung secara dinamis. unsur-unsur yang ada didalamnya bergerak aktif, dinamis, dan tidak statis.

Salah satu kelebihan model ini adalah tidak terbatas pada komunikasi public atau komunikasi masa, namun juga komunikasi antar pribadi dan berbagai bentuk komunikasi tertulis. Model ini bersifat heuristic (merangsang penelitian). Karena merinci unsur-unsur penting dalam komunikasi, model ini dapat menjelaskan tentang efek keterampilan komunikasi penerima atas penerimaan pesan yang dikirimkan.

\subsection{Keberhasilan Komunikasi Bisnis Perbankan Syariah}

Keberhasilan komunikasi bisnis dalam suatu organisasi akan ditentukan oleh kesamaan pemahaman antara orang yang terlibat dalam kegiatan komunikasi, kesamaan pemahaman ini dipengaruhi oleh kejelasan pesan, cara penyampaian pesan, perilaku komunikasi dan situasi. Komunikasi organisasi biasanya menggunakan kombinasi cara berkomunikasi (lisan, tertulis dan tayangan) yang memungkinkan terjadinya penyerapan informasi dengan lebih mudah dan jelas.

Secara empiris, pemahaman orang perihal suatu halakan lebih mudah diserap dan dipahami jika sesuatu tersebut diperlihatkan disbanding hanya diperdengarkan atau dibacakan. Dan akan lebih baik lagi hasilnya jika sesuatu yang dikomunikasikan tersebut dapat dipraktikkan. 
Hasil studi tentang perilaku bisnis di kalangan eksekutif menunjukan fakta bahwa kemampuan berkomunikasi merupakan unsur pokok diantara berbagai faktor personal yang diperlukan untuk mempromosikan manajemen organisasi atau mengatasi konflik manajemen. Keberhasilan komunikasi bisnis juga sangat ditentukan oleh adanya efektifitas dalam komunikasi bisnis, seperti halnya jenis komunikasi lainnya ditentukan oleh :

1. Persepsi

Komunikator harus memprediksi apakah pesan yang disampaikan dapat diterima komunikan.

2. Keberhasilan teknologi informasi dan komunikasi

Salah satu factor keberhasilan komunikasi bisnis dalam penggunaan teknologi informasi dan komunikasi yaitu adanya proses integrase informasi menyangkut ketersediaan komunikasi data yang tepat guna. Ini mencakup beberapa faktor antara lain : range produk jasa, komunikasi data yang dimiliki, unjuk kerja, dan coverage.

3. Ketepatan

Komunikan atau audience memiliki kerangka piker, agar komunikasi yang dilakukan tepat sasaran, komunikator perlu mengekspresikan hal yang ingin disampaikan sesuai dengan kerangka piker komunikan.

4. Kredibilitas

Dalam berkomunikasi komunikator perlu memiliki suatu keyakinan bahwa komunikan dapat dipercaya. Sebaliknya dia juga dapat kepercayaan dari komunikan.

5. Pengendalian

Dalam komunikasi, komunikan memberikan reaksi/umpan balik/feedback terhadap pesan yang disampaikan. Reaksi ini harus bias diantisipasi sekaligus dikendalikan oleh komunikator sehingga tidak melencengdari target komunikasi yang diharapkan.

6. Kecocokan

Komunikator yang baik selalu dapat menjaga hubungan persahabatan yang menyenangkan dengan komunikan.

Dengan demikian apabila komunikasi bisnis berjalan secara efektif akan dapat mengahsilkan beberapa hal, diantaranya mempercepat penyelesaian, memberikan 
respon yang positif terhadap stakeholder, meningkatkan produktivitas, dan memperkuat hubungan bisnis.

\subsection{Komunikasi Bisnis Perbankan Syariah dalam Konteks Dakwah}

Komunikasi bisnis yang dijalankan oleh perbankan syariah secara tidak langsung mengkomunikasikan pesan-pesan dakwah, hal tersebut dapat diidentifikasi dari berbagai transaksi bisnis yang dilakukan oleh perbankan syariah tersebut. Produk yang ditawarkan oleh perbankan syariah dapat menjadi cerminan produk islami yang sesuai dengan syariat islam, seperti Murabahah yang merupakan produk unggulan perbankan syariah lending sampai dengan tabungan haji dan umroh.

Dalam konteks dakwah, komunikasi bisnis merupakan kegiatan dakwah secara langsung dan tidak langsung. Segala aktivitas bisnis yang dijalankanmengkomunikasikan pesan-pesan dakwah islam. Perbankan syariah juga berkomitmen untuk memberikan produk dan pelayanan yang islami. Seperti yang dijalankan oleh bank Mega Syariah yang merupakan bagian dari CT Corp, menjalankan aktivitas perbankan khususnya funding dan lending sesuai dengan prinsip syariah. Produk yang ditawarkan juga memiliki muatan syariah, sebagai contoh tidak adanya bunga dalam produk lending yang diganti dengan margin, akad kredit yang dilakukan juga berbeda dengan perbankan konvensional. Dalam akad kredit Murabahah, jelas sekali diterangkan kepada nasabah berapa keuntungan perbankan yang akan dibayar sesuai dengan tenor yang diambil.

Walaupun demikian, komunikasi bisnis perbankan syariah juga terkendala oleh berbagai faktor, seperti lemahnya sumber daya manusia yang dimiliki perbankan syariah itu sendiri, kurang mengerti tentang produk yang ditawarkan, serta pemahaman atau paradigm masyarakat yang belum sepenuhnya tentang perbankan syariah dll. 


\section{BAB III}

\section{PENUTUP}

\subsection{KESIMPULAN}

Perbankan syariah telah menjalankan aktivitas bisns yang mengkomunikasikan pesan-pesan dakwah kepada khalayak, dalam hal ini adalah nasabah dan masyarakat. Secara tidak langsung perbankan syariah telah menjalankan aktivitas dakwah, walaupun tujuan akhir dari perbankan syariah adalah mendapat keuntungan bisnis. Aktivitas dakwah yang dilakukan oleh perbankan syariah teridentifikasi dari berbagai proses operasional perbankan, seperti pelayanan kepada nasabah, prospek nasabah, produk yang ditawarkan, media yang digunakan untuk menawarkan produk, dll. 


\section{DAFTAR PUSTAKA}

Rohayati. 2019. Aktifitas Bisnis Perbankan Syariah Dalam Perspektif Komunikasi Dakwah. Idarotuna, Vol ;. 2, No. 1.

Syarif, Nasrul 2019. Komunikasi Kontemporer: Bisnis Islam di Era Digital. Yogjakarta : Indonesia, Deepublish

Nawir Munawir. 2020. Etika dan Komunikasi dalam Bisnis: Tinjauan Al-Qur'an, Filsafat dan Teoritis. Indonesia, CV. Social Politic Genius (SIGn) 